\title{
The Relationship Knowledge with The Effort to Eliminate Behavior of Eradication Mosquitonest in The Attempt to Prevent Disease Dengue in The Village Sumbermulyo Bambanglipuro Bantul
}

\author{
Hubungan Pengetahuan dengan Perilaku \\ Pemberantasan Sarang Nyamuk dalam Upaya \\ Pencegahan Penyakit Demam Berdarah di Desa \\ Sumbermulyo Bambanglipuro Bantul
}

Siti Arifah

\begin{abstract}
Dengue hemorrhagic fever (DHF) is an endemic disease in Bantul district. Counselling of pandemic Society and mosquito eradication program has been conducted to increase knowledge and the chance of happened behavioral change the effort to eliminate behavior of eradication mosquitonest. But infect Dengue Hemorragic Fever insidensi still be high. There are three factor play a part in infection of DHFdisease, that is virus agent, human being and environment, beside Aedes aegypti mosquito as infection vektors such as.Goal of: The relationship of knowledge with the effort to eliminate behavior of eradication mosquitonest in the attempt preventing of disease dengue in Sumbermulyo Bambanglipuro Bantul. Method: This research was a quantitative research with descriptive method survey. 77 people was taken by using Non Probability sampling technique with Purposive Sampling method. Test Validity is product moment pearson and test reliabilitas is cronbach alpha and continued with Chi Square data analysis. Prevalency value $<1$.

Chi-square was used to analize data. Result of: to the result of this study was 0,453 . This result indicatied that there was no relationship between knowledge and PSN's behaviors in this Village Sumbermulyo Bambanglipuro Bantul. It is recommended to increase the community knowledge about the PSN program by using the appropriate strategy. The level of knwledge and the effort to eliminate behavior of eradication mosquitonest
\end{abstract}

Keywords: the level of knowledge, the effort to eliminate behavior of eradication mosquitonest

\footnotetext{
Afiliasi Penulis

Prodi D3 Teknik Radiodiagnostik dan Radioterapi STIKes Guna

Bangsa Yogyakarta

Korespondensi kepada

S. Arifah

sitiarifah9090@gmail.com
} 
Demam berdarah dengue (DBD) merupakan penyakit yang endemis di kabupaten Bantul. Penyuluhan masyarakat tentang penyakit DBD dan program pemberantasan sarang nyamuk (PSN) telah dilakukan untuk meningkatkan pengetahuan dan dengan harapan terjadi perubahan perilaku pemberantasan sarang nyamuk (PSN). Tetapi insidensi DBD masih terus tinggi. Tiga faktor yang berperan dalam penularan penyakit DBD, yaitu virus (agen), manusia (penjamu), dan lingkungan, di samping nyamuk Aedes aegypti sebagai vektor penularan. Tujuan dari penelitian ini untuk mengetahui hubungan pengetahuan dengan perilaku pemberantasan sarang nyamuk dalam upaya pencegahan penyakit demam berdarah di desa Sumbermulyo Bambanglipuro Bantul. Metode penelitian ini merupakan penelitian kuantitatif dengan metode deskriptif survey. Dalam penelitian ini digunakan sampel sebanyak 77 orang dengan menggunakan dengan menggunakan teknik Non Probability sampling dengan metode purposive sampling. Uji validitas menggunakan uji pearson product moment sedangkan uji reliabilitas menggunakan alfa cronbach dan dilanjutkan dengan analisis data Chi Square. Nilai Ratio Prevalensi yaitu $\mathrm{RP}<1$. Analisis data menggunakan chi-square diperoleh nilai koefisiensi korelasi sebesar 0,563 dengan nilai probabilitas 0,556 yang menunjukkan bahwa tidak ada hubungan antara pengetahuan dengan perilaku PSN di desa Sumbermulyo Bambanglipuro Bantul.. Disarankan untuk meningkatkan pengetahuan masyarakat tentang program PSN dengan strategi yang tepat. Tingkat pengetahuan dan perilaku pemberantasan sarang nyamuk

Kata Kunci: Tingkat pengetahuan, perilaku pemberantasan sarang nyamuk

\section{Pendahuluan}

Demam Berdarah Dengue (DBD) adalah infeksi virus yang dibawa oleh Aedes Aegypti dan merupakan masalah kesehatan nasional. Ini merupakan penyakit endemis yang ada di Indonesia dan muncul secara episodik di alam dan terjadi tahunan. Aedes Aegypti adalah jenis nyamuk pembawa Demam Berdarah dengan karakteristik memiliki strip hitam dan putih pada tubuhnya. Kongres Kesehatan Sedunia yang ke-46 telah menyetujui sebuah resolusi tentang upaya pencegahan penyakit DBD dan pemberantasannya, yang kemudian melahirkan pemikiran bahwa pemberdayaan program pencegahan dan pemberantasan penyakit DBD yang berskala nasional maupun lokal adalah ditingkatkannya penyuluhan kesehatan kepada masyarakat (2).

Kabupaten Bantul merupakan daerah endemis. Angka kejadian penyakit demam berdarah pada tahun 2015 adalah 30,85 per 100.000 penduduk dengan angka kematian kasus 1,38\%. Angka Bebas Jentik Kabupaten Bantul tahun 2016 adalah 89,7\%. Kasus DBD sampai dengan bulan Desember 2015 sejumlah 103 kasus dengan jumlah kasus meninggal 3 orang (4).

Desa Sumbermulyo Bambanglipuro Bantul memiliki kasus demam berdarah terbanyak yaitu 3 kasus. Upaya untuk pencegahan dan pemberantasan penyakit demam berdarah yang paling penting adalah mengendalikan nyamuk Aedes Aegypti sebagai vektor utama. Karena nyamuk tersebut hidup di dalam dan sekitar rumah penduduk, maka partisipasi masyarakat dalam pencegahan sangat diperlukan yaitu dengan program penberantasan sarang nyamuk (PSN). Berdasarkan pengamatan penulis di Desa Sumbermulyo perilaku untuk memberantas sarang nyamuk masih kurang terbukti masih tingginya angka kejadian penyakit demam berdarah dan masih terdapat pendapat di masyarakat bahwa seseorang menderita demam berdarah, masyarakat langsung meminta dilakukan pengasapan tanpa diikuti PSN. Pengetahuan masyarakat tentang penyakit demam berdarah sangat berpengaruh terhadap perilaku pencegahan penyakit demam berdarah dan pelaksanaan program PSN (5).

Studi ini menunjukkan bahwa, secara umum pengetahuan masyarakat tentang nyamuk adalah sebagai hewan pengganggu karena gigitannya, bukan sebagai vektor pembawa penyakit. Kurangnya kesadaran masyarakat mengenai cara perilaku hidup bersih dan sehat (PHBS), terutama penyimpanan air bersih yang benar dan minimnya ventilasi menjadikan rumah lembab, sehingga 
rumah menjadi sarana pertumbuhan yang baik bagi nyamuk. Oleh karena itu peneliti ingin mengetahui adakah hubungan antara pengetahuan dengan perilaku pemberantasan sarang nyamuk dalam upaya pencegahan penyakit demam berdarah di desa Sumbermulyo Bambanglipuro Bantul $(5,17$, 18).

Penelitian ini bertujuan untuk mengetahui hubungan tingkat pengetahuan masyarakat dengan perilaku pemberantasan sarang nyamuk dalam upaya pencegahan penyakit demam berdarah di desa Sumbermulyo Bambanglipuro Bantul.

\section{Metode}

Jenis penelitian adalah penelitian kuantitatif non eksperimental sedangkan metode yang digunakan deskriptif survei (12). Populasi dalam penelitian ini adalah kepala rumah tangga di desa Sumbermulyo Bambanglipuro Bantul pada tahun 2015 yang berjumlah 324 orang. Sampelnya yaitu kepala keluarga di desa Sumbermulyo Bambanglipuro Bantul. Teknik pengambilan sampel menggunakan Non Probability Sampling dengan metode purposive sampling. Menggunakan rumus Krej Cie Normogorof King (12). Dari 324 kepala rumah tangga peneliti mendapatkan jumlah sampel sebanyak 77 responden. Kriteria sampel harus memenuhi kriteria inklusi yaitu: berdomisili di Desa Sumbermulyo, responden adalah kepala rumah tangga, umur 25-45 tahun, pendidikan minimal lulus sekolah dasar atau orang yang dapat membaca dan menulis, bersedia menjadi subyek penelitian.

Kriteria eksklusi dalam penelitian ini adalah kepala rumah tangga yang tidak hadir pada saat penelitian. Instrumen penelitian ini menggunakan kuesioner yang sudah di uji validitas dan reliabilitas di Puskesmas Jetis Bantul. Hasil uji validitas menggunakan korelasi product moment, pengetahuan responden mengenai PSN dari 20 item kuesioner yang diujicobakan, dinyatakan tidak valid ada 5 item pertanyaan, yaitu dengan $r$ tabel $=$ 0,334 . Hasil uji reliabilitas menggunakan Alfa Cronbach sebesar 0,95 yang artinya signifikan, karena berada diatas 0,05. Dari nilai nilai koefisien reliabilitas tersebut, dapat dinyatakan bahwa alat ukur tersebut adalah reliabel.
Lokasi penelitian ini di desa Sumbermulyo yang termasuk salah satu desa binaan puskesmas Bambanglipuro. Dilaksanakan pada bulan Februari 2016. Analisa data dilakukan untuk tujuan menjawab hipotesis penelitian. Analisa korelasi yang digunakan untuk mengetahui hubungan pengetahuan dengan Perilaku pemberantasan sarang nyamuk digunakan uji chi-square.

\section{Hasil dan Pembahasan}

\section{Karakteristik Responden}

Secara rinci deskripsi responden dapat diuraikan pada Tabel 1 berikut ini yang menggambarkan karakteristik responden meliputi umur, pendidikan, pengetahuan dan perilaku. Berdasarkan Tabel 1 diketahui umur responden terbanyak berumur 40-45 tahun yaitu 31 responden atau $40,25 \%$, serta yang paling sedikit yaitu berumur 25-30 tahun yaitu sebanyak 10 responden atau $12,98 \%$. Jadi sebagian besar jumlah responden dalam penelitian ini adalah responden dengan umur 41-45 tahun. Berdasarkan pendidikan menunjukkan bahwa sebagian besar pendidikan responden dalam penelitian ini adalah SMA yaitu sebanyak 30 responden atau 38,96\% dan paling sedikit yaitu perguruan tinggi yaitu sebanyak 9

Tabel 1 | Karakteristik Responden
Karakteristik Responden

Umur

\begin{tabular}{|c|c|c|c|}
\hline \multicolumn{4}{|l|}{ Umur } \\
\hline & $25-30$ & 10 & 12,98 \\
\hline & $30-35$ & 12 & 15,59 \\
\hline & $35-40$ & 24 & 31,17 \\
\hline & $40-45$ & 31 & 40,26 \\
\hline \multicolumn{4}{|l|}{ Pendidikan } \\
\hline & SD & 12 & 15,58 \\
\hline & SMP & 26 & 33,77 \\
\hline & SMA & 30 & 38,96 \\
\hline & PT & 9 & 11,69 \\
\hline \multicolumn{4}{|l|}{ Pengetahuan } \\
\hline & Baik & 67 & 87,0 \\
\hline & Tidak Baik & 10 & 13,0 \\
\hline \multicolumn{4}{|l|}{ Perilaku } \\
\hline & Baik & 54 & 70,1 \\
\hline & Tidak Baik & 23 & 29,9 \\
\hline
\end{tabular}

Pendidikan

\begin{tabular}{|c|c|c|c|}
\hline \multicolumn{4}{|l|}{ Umur } \\
\hline & $25-30$ & 10 & 12,98 \\
\hline & $30-35$ & 12 & 15,59 \\
\hline & $35-40$ & 24 & 31,17 \\
\hline & $40-45$ & 31 & 40,26 \\
\hline \multicolumn{4}{|l|}{ Pendidikan } \\
\hline & SD & 12 & 15,58 \\
\hline & SMP & 26 & 33,77 \\
\hline & SMA & 30 & 38,96 \\
\hline & PT & 9 & 11,69 \\
\hline \multicolumn{4}{|l|}{ Pengetahuan } \\
\hline & Baik & 67 & 87,0 \\
\hline & Tidak Baik & 10 & 13,0 \\
\hline \multicolumn{4}{|l|}{ Perilaku } \\
\hline & Baik & 54 & 70,1 \\
\hline & Tidak Baik & 23 & 29,9 \\
\hline
\end{tabular}

Pengetahuan

\begin{tabular}{|c|c|c|c|}
\hline \multicolumn{4}{|l|}{ Umur } \\
\hline & $25-30$ & 10 & 12,98 \\
\hline & $30-35$ & 12 & 15,59 \\
\hline & $35-40$ & 24 & 31,17 \\
\hline & $40-45$ & 31 & 40,26 \\
\hline \multicolumn{4}{|l|}{ Pendidikan } \\
\hline & SD & 12 & 15,58 \\
\hline & SMP & 26 & 33,77 \\
\hline & SMA & 30 & 38,96 \\
\hline & PT & 9 & 11,69 \\
\hline \multicolumn{4}{|l|}{ Pengetahuan } \\
\hline & Baik & 67 & 87,0 \\
\hline & Tidak Baik & 10 & 13,0 \\
\hline \multicolumn{4}{|l|}{ Perilaku } \\
\hline & Baik & 54 & 70,1 \\
\hline & Tidak Baik & 23 & 29,9 \\
\hline
\end{tabular}

Perilaku

\begin{tabular}{|c|c|c|c|}
\hline \multicolumn{4}{|l|}{ Umur } \\
\hline & $25-30$ & 10 & 12,98 \\
\hline & $30-35$ & 12 & 15,59 \\
\hline & $35-40$ & 24 & 31,17 \\
\hline & $40-45$ & 31 & 40,26 \\
\hline \multicolumn{4}{|l|}{ Pendidikan } \\
\hline & SD & 12 & 15,58 \\
\hline & SMP & 26 & 33,77 \\
\hline & SMA & 30 & 38,96 \\
\hline & PT & 9 & 11,69 \\
\hline \multicolumn{4}{|l|}{ Pengetahuan } \\
\hline & Baik & 67 & 87,0 \\
\hline & Tidak Baik & 10 & 13,0 \\
\hline \multicolumn{4}{|l|}{ Perilaku } \\
\hline & Baik & 54 & 70,1 \\
\hline & Tidak Baik & 23 & 29,9 \\
\hline
\end{tabular}

Sumber: Data Primer Tahun 2015

\section{(n) (\%)}


responden atau $11,69 \%$. Berdasarkan deskripsi statistik diketahui jumlah responden yang memiliki pengetahuan baik ada 67 responden $(87,0 \%)$ dan responden yang mempunyai pengetahuan yang tidak baik sebanyak 10 responden (13,0\%). Berdasarkan gambaran perilaku dari 77 responden menunjukkan bahwa 54 responden (70,1\%) mempunyai perilaku yang baik dan 23 responden $(29,9 \%)$ mempunyai perilaku yang tidak baik tentang PSN.

Penelitian Nalongsack menggambarkan dimana dari 230 sampel yang diteliti, 163 (70,9\%) memiliki pengetahuan yang baik mengenai vektor penyebab DBD. Untuk 101 (43,9\%) responden, sumber utama informasi tentang DBD adalah teman atau kerabat. Hal ini mendorong 217 (94,3\%) responden memiliki sikap positif bahwa DBD dapat diobati dan 222 (96,5\%) mengetahui mereka harus mengunjungi dokter ketika terjangkit DBD (18).

\section{Hubungan Pengetahuan dengan Perilaku PSN dalam Upaya Pencegahan Penyakit Demam \\ Berdarah}

Secara rinci hubungan pengetahuan dengan perilaku PSN dalam upaya pencegahan penyakit demam berdarah diuraikan pada Tabel 2 . Berdasarkan Tabel 2 di atas diketahui jumlah responden yang mempunyai pengetahuan kurang baik dan berperilaku tidak baik ada 4 responden $(5,2 \%)$ dan 6 orang $(7,8 \%)$ mempunyai pengetahuan tidak baik tetapi perilakunya baik. Responden yang berpengetahuan tidak baik dan perilakunya baik ada 19 responden $(24,7 \%)$ sedang 48 responden $(62,3 \%)$ mempunyai pengetahuan baik dan perilaku baik.

Hasil analisis diperoleh nilai chi-square sebesar 0,563 dengan probabilitas sebesar 0,453. Nilai probabilitas menunjukkan bahwa nilai probabilitas lebih kecil dari level of significant $5 \%(0,538<0,05)$, berarti Ho diterima dan $\mathrm{Ha}$ ditolak. Maka dapat disimpulkan bahwa tidak ada hubungan antara pengetahuan dengan perilaku pemberantasan sarang nyamuk dalam upaya pencegahan penyakit demam berdarah.

Pengetahuan responden yang tidak baik berjumlah 10 (13\%) dan yang berpengetahuan baik berjumlah 67 (87\%). Pengetahuan adalah hasil dari proses belajar yang berupa pengenalan dan pengingatan kembali hal-hal yang berhubungan dengan fakta, istilah, konsep dan lain-lain (13). Pengetahuan tentang pencegahan DBD adalah hasil belajar seseorang yang dapat diperoleh melalui berbagai cara seperti membaca dari buku, informasi dari media massa cetak maupun elektronik atau dari penyuluhan oleh petugas kesehatan. Shuaib menemukan bahwa radio dan televisi merupakan sumber yang dominan mempengaruhi pengetahuan. (10) Pengetahuan merupakan hasil dari tahu dan ini terjadi setelah orang melakukan penginderaan terhadap obyek tertentu. Pengetahuan tentang penyakit demam berdarah berdampak pada pemahaman tindakan yang seharusnya diberikan oleh para medis dalam upaya penyembuhan penyakit demam berdarah. Pperilaku yang baik terhadap penatalaksanaan penyakit demam berdarah mendukung tercapainya kesembuhan pasien secara optimal.

Pada Nilai Prevalensi didapatkan nilai RP $<1$ yang artinya pengetahuan masyarakat tentang pencegahan penyakit Demam Berdarah menjadi penyebab menurunnya perilaku PSN. Penyimpangan-penyimpangan tersebut dapat terjadi karena adanya faktor lain yang berhubugan dengan perilaku seseorang terhadap pencegahan penyakit demam berdarah. mengemukakan faktor-

Tabel 2 | Hubungan Pengetahuan dengan Perilaku PSN dalam Upaya Pencegahan Penyakit Demam Berdarah.

\begin{tabular}{|c|c|c|c|c|c|c|c|c|}
\hline \multirow{3}{*}{ Pengetahuan } & \multicolumn{4}{|c|}{ Perilaku PSN } & \multirow{2}{*}{\multicolumn{2}{|c|}{ Total }} & \multirow{3}{*}{$p$-value } & \multirow{3}{*}{$x^{2}$} \\
\hline & \multicolumn{2}{|c|}{ Tidak Baik } & \multicolumn{2}{|c|}{ Baik } & & & & \\
\hline & $n$ & $\%$ & $\mathrm{n}$ & $\%$ & $n$ & $\%$ & & \\
\hline Tidak Baik & 4 & 5,2 & 6 & 7,8 & 10 & 13 & 0,453 & 0,538 \\
\hline Baik & 19 & 24,7 & 48 & 62,3 & 67 & 87 & & \\
\hline Total & 23 & $29,9,9$ & 54 & 70,1 & 77 & 100 & & \\
\hline
\end{tabular}

Sumber: Data Primer Tahun 2016 
faktor pembentuk perilaku lainnya misalnya kebudayaan, orang lain yang dianggap penting, media massa, institusi, atau lembaga pendidikan, pengalaman pribadi, dan faktor emosi dalam diri individu lewat pendekatan pembelajaran sosial menyebutkan bahwa pembentukan atau perubahan sikap orang dewasa terjadi melalui terpaparnya cara baru untuk melakukan sesuatu kegiatan melalui tindakan yang dilakukan oleh kawan, rekan kerja, orang tua atu saudara. Kedua pendapat tersebut menunjukkan bahwa faktor lain diluar pengetahuan mampu mempengaruhi perilaku seseorang. Faktor-faktor yang mempengaruhi perilaku seseorang adalah faktor genetik atau faktor endogen, faktor eksogen atau faktor dari luar individu dan faktor lingkungan. Lingkungan disini menyangkut segala sesuatu yang ada di sekitar individu, baik fisik, biologis maupun sosial.

Ditinjau dari distribusi tingkat pendidikan responden yang baik yaitu sebagian besar berpendidikan SMA yaitu sebanyak 30 responden $(38,96)$ maka tingkat pengetahuan tersebut adalah cukup. Dalam analisis univariat penelitian Shuaib F., et al, hubungan antara pengetahuan dengue, sikap, praktek dan karakteristik sosio-demografis dari kelompok studi, ditemukan peluang peningkatan pengetahuan tentang demam berdarah, pada responden yang telah menyelesaikan pendidikan menengah (Odds Ratio (OR): 2,00; 95\% Confidence Interval (Cl), 1,04-3,85). Untuk responden yang menyelesaikan studi perguruan tinggi atau pasca kuliah (OR, 2.98; 95\% $\mathrm{Cl}, 1,23-7,23)$. Tidak ada hubungan signifikan yang ditemukan antara praktik pencegahan dan karakteristik sosio-demografis dengan perubahan perilaku PSN (11).

Perilaku PSN yang tidak baik sejumlah 23 responden $(29.9 \%)$ dan yang berperilaku baik sejumlah 54 responden $(70,1 \%)$. Perilaku terhadap pencegahan demam berdarah menurut model perubahan perilaku yang dikembangkan(10) meliputi tahap pertama yaitu unfreezing, yaitu ketika seseorang menyadari bahwa tindakannya selama ini kurang tepat, sehingga muncul penyakit demam berdarah. Tahap kedua yaitu changing (perubahan) yaitu setelah terbukanya kesadaran seseorang tentang tindakannya selama ini, maka terbentuk perilaku baru tentang pencegahan demam berdarah. Perubahan perilaku ini dipengaruhi oleh pengetahuan yang diterima seseoarang serta pengaruh dari lingkungan sekitar baik informasi maupun pengaruh orang lain. Tahap ketiga yaitu Re-freezing, tahap ini seseorang mengevaluasi perilakunya terhadap pencegahan demam berdarah tersebut telah sesuai dengan harapannya atau tidak.

Perilaku responden dalam pencegahan demam berdarah adalah relatif baik sebanyak 54 responden $(70,1 \%)$ dan yang berperilaku kurang baik sejumlah 23 responden (29.9\%). Deskripsi perilaku responden dalam pencegahan demam berdarah berada pada kisaran baik. Menurut penelitian Shuaib F., et al, responden melakukan kegiatan preventif untuk menghindari kontak dengan nyamuk, misalnya $61,7 \%$ responden menggunakan semprotan insektisida; 56,4\% mempercayakan pada petugas layanan pengendalian hama profesional; $22,9 \%$ memasang jaring saring pada jendela dan $4,8 \%$ menggunakan kelambu pada malam hari. (11)

Penelitian terdahulu yang dilakukan (9), yang meneliti tentang persepsi dan perilaku partisipasi dalam program penanggulangan penyakit demam berdarah dengue oleh masyarakat terdapat hubungan persepsi yang baik menimbulkan perilaku yang baik pula dalam pencegahan penyakit demam berdarah. Hasil penelitian yang dilakukan oleh peneliti saat ini tidak mendukung teori yang ada atau tidak mendukung penelitian sebelumnya. Kesimpulan yang diperoleh peneliti yaitu tidak terdapat hubungan antara pengetahuan masyarakat tentang penyakit demam berdarah dengan perilaku pemberantasan sarang nyamuk dalam upaya pencegahan penyakit demam berdarah di Desa Sumbermulyo Bambanglipuro Bantul. Ini terlihat dari hasil nilai ratio prevalensi kurang dari satu yang artinya pengetahuan yang baik belum tentu mempengaruhi perilaku yang baik pula. Pengetahuan tidak selalu ada keterkaitan dengan perilaku karena bisa jadi orang yang berpengetahuan baik melakukan perilaku yang bertentangan dengan pengetahuannya sendiri.

Penelitian yang dilakukan oleh erni nuryanti dengan judul perilaku pemberantasan sarang nyamuk di masyarakat di dapatkan simpulan 
penelitian, pengetahuan, sikap, ketersediaan informasi, dan peran petugas kesehatan berpengaruh terhadap perilaku pemberantasan sarang nyamuk demam berdarah dengue di masyarakat.

Penelitian dengan judul hubungan perilaku pemberantasan sarang nyamuk dan kejadian demam berdarah dengue di kota bandar lampung oleh amrul hasan, dian ayubi menunjukkan hasil penelitian ini menemukan bahwa ada hubungan kebiasaan melakukan psn dengan kejadian demam berdarah dengue

Penelitian yang dilakukan oleh sang gede purnama dan kawan kawan dengan judul pengetahuan, sikap dan perilaku pemberantasan sarang nyamuk terhadap infeksi dengue di kecamatan denpasar selatan, kota denpasar, bali menujukkan hasilpenelitian ada pengaruh antara faktor risiko tingkat pengetahuan, sikap dan perilaku dengan kejadian $\mathrm{dbd}$

Penelitian dengan judul hubungan antara pengetahuan dan sikap terhadap perilaku pemberantasan sarang nyamuk (psn) sebagai pencegahan demam berdarah dengue $(\mathrm{dbd}) \mathrm{di}$ banjar badung, desa melinggih, wilayah puskesmas payangan tahun 2014 oleh ni nyoman yunita kusuma bakta, i made bakta menunjukkan penelitian ini dapat disimpulkan bahwa tingkat pendidikan, pengetahuan tentang demam berdarah dengue, dan sikap yang mendukung perilaku PSN berhubungan secara signifikan dengan perilaku PSN, dimana semakin tinggi tingkat pendidikan, semakin baik pengetahuan tentang demam berdarah dan dengan sikap yang mendukung psn, maka akan dilakukan perilaku PSN yang benar

\section{Kesimpulan}

Berdasarkan hasil penelitian maka dapat disimpulkan bahwa pengetahuan tidak mempunyai hubungan yang signifikan dengan perilaku PSN. Jadi hipotesis yang menyatakan bahwa "Ada hubungan pengetahuan dengan perilaku hidup bersih dan sehat dalam upaya pencegahan penyakit DBD pada masyarakat di desa Sumbermulyo Bambanglipuro Bantul", tidak terbukti kebenarannya.
Hasil ini berbeda dengan penelitian orang lain. Untuk itu perlu dikaji ulang dan mencari faktor penyebab perilaku pemberantasan nyamuk di wilayah sumbermulyo untuk mendapatkan hasil yang lebih baik lagi.

Bagi kepala dan perangkat desa Sumbermulyo untuk memberikan pengarahan kepada masyarakat tentang penyakit demam berdarah guna meningkatkan perilaku masyarakat terhadap penatalaksanaan dan pencegahan penyakit demam berdarah.

\section{Bibliografi}

1. Azwar, A Pengantar Administrasi Kesehatan, Edisi Ketiga, Jakarta: Binarupa Aksara; 2010.

2. Depkes RI, Sistem Kesehatan Nasional, Jakarta. Depkes Rl; 2012.

3. Dinkes Kabupaten Bantul, Profil Kesehatan Kabupaten Bantul; 2015,

4. Dinkes Kabupaten Bantul Laporan Tahunan Penyakit Menular di Kabupaten Bantul; 2015.

5. Liu et all., Community Knowledge and Experience of Mosquitoes and Personal Prevention and Control Practices in Lhasa, Tibet. Int J Environ Res Public Health. 2014 Sep; 11(9): 9919-9937

6. Neil, Niven.. Psikologi Kesehatan. Pengantar untuk perawat dan profesional kesehatan lain. Jakarta, Buku Kedokteran EGC: 2012

7. Notoatmodjo, S., IImu Kesehatan Masyarakat : Prinsip-prinsip Dasar, Jakarta. PT. Rineka Cipta; 2012.

8. Nur Salam, Siti Pariani. Metodologi Riset Keperawatan, Jakarta, 2011.

9. Sombowidjojo Persepsi Perilaku Partisipasi dalam Program Penanggulangan Penyakit Demam Berdarah Dengue oleh Masyarakat di wilayah Puskesmas Magelang Selatan Kotamadya Dati II Magelang. Universitas Gajah Mada, Thesis, 2014

10. WHO (2010). Guidelines for Pevention and Control of Dengue. Zoonosis Division, National Institute of Communicable Diseases (Directorate Ceneral of Health Services). 22- Sham Nath Marg, Delhi - 110054

11. Shuaib F., et al. Knowledge, attitudes and practices regarding dengue infection in Westmoreland, Jamaica. West Indian Med J. 2010; 59(2): 139-146.

12. Machfoedz, I., Pendidikan Kesehatan Bagian dari Promosi Kesehatan, Cetakan Keempat, Penerbit Fitramaya, Yogyakarta 2005 
13. Hadinegoro, Sri R., Satari H., Demam Berdarah Dengue. Balai Penerbit Fakultas Kedokteran Universitas Indonesia.2007

14. Aryu Candra., Demam Berdarah Dengue: Epidemiologi, Patogenesis, dan Faktor Resiko Penularan., Jurnal Litbang Depkes., 2010

15. Alyousefi TA et all., A household-based survey of knowledge, attitudes and practices towards dengue fever among local urban communities in Taiz Governorate, Yemen., BMC infect dis 2016 Oct 7;16(1):54

16. Makornkan., Knowledge, Attitude and Practice of Dengue Fever Prevention Among the Villagers of Moo 1 Baan Klongsai, Nhongyangsuea Subdistrict, Muaklek District, Saraburi Province, Thailand, ISSN: 2408-137XVolume 12, No. 2,2015.

17. Kaul SM et all., Community perception of mosquitos and mosquito control in some areas of urban Delhi and rural Alwar, Rajasthan. J Commun Dis. 1995 Dec;27(4):215-22.

18. Nalongsack $S$ et all., Knowledge, attitude and practice regarding dengue among people in Pakse, laos. Nagoya j med sci. 2009 feb;71(1. 2):29-37.

19. Erni nuryanti, Perilaku Pemberantasan Sarang Nyamuk Di Masyarakat, Vol 9, No 1 (2013) halaman 15-23 KEMAS http://journal.unnes.ac.id/artikel_nju/kemas/2825

20. Amrul Hasan, Dian Ayubi, Hubungan Perilaku Pemberantasan Sarang Nyamuk dan Kejadian Demam Berdarah Dengue di Kota Bandar Lampung, KESMAS, Jurnal Kesehatan Masyarakat Nasional Vol. 2, No. 2, Oktober 2007 hal: $86-90$ 